\title{
Drinking Water Quality on Chronic Kidney Disease of Unknown Aetiology (CKDu) in Ulagalla Cascade, Sri Lanka
}

\author{
W.C.S. Wanasinghe ${ }^{1}$, M.H.J.P.Gunarathna ${ }^{2}$, H.M.P.I.K.Herath ${ }^{3}$, and G.Y.Jayasinghe ${ }^{1^{*}}$ \\ ${ }^{1}$ Faculty of Agriculture, University of Ruhuna, Sri Lanka \\ ${ }^{2}$ Faculty of Agriculture, Rajarata University of Sri Lanka \\ ${ }^{3}$ Faculty of Technology, University of Colombo, Sri Lanka \\ * jayasinghe@ageng.ruh.ac. $1 \mathrm{k}$
}

\begin{abstract}
Chronic Kidney Disease of unknown aetiology (CKDu) is one of the major health issues in Northern part of Sri Lanka that recorded highest mortality and morbidity rates. The main responsible reason for the CKDu has not yet been identified and hence many scientists have suggested number of certain risk factors where the CKDu-mfo (CKDu multi-factorial origin) term derived. However it relates with certain drinking water quality parameters strongly. This study was focused on evaluating the drinking water quality of Ulagalla cascade in Anuradhapura district with admiration to CKDu. Thirty wells and twenty tanks were selected as sampling locations for groundwater $(\mathrm{GW})$ and surface water $(\mathrm{SW})$ respectively from the cascade. Water quality parameters such as $\mathrm{pH}$, electrical conductivity (EC), total dissolved solids (TDS), turbidity, Sodium $\left(\mathrm{Na}^{+}\right)$, Magnesium $\left(\mathrm{Mg}^{2+}\right), \mathrm{Calcium}$ $\left(\mathrm{Ca}^{2+}\right)$, Potassium $\left(\mathrm{K}^{+}\right)$, Arsenic $\left(\mathrm{As}^{2+}\right)$, Lead $\left(\mathrm{Pb}^{2+}\right)$, Cadmium $\left(\mathrm{Cd}^{2+}\right)$, Ammonium Nitrogen $\left(\mathrm{NH}_{4}{ }^{+}-\mathrm{N}\right)$, Nitrate Nitrogen $\left(\mathrm{NO}_{3}{ }^{-}-\mathrm{N}\right)$, alkalinity, Sulphate $\left(\mathrm{SO}_{4}{ }^{2-}\right.$, Chloride $\left(\mathrm{Cl}^{-}\right)$and Phosphate $\left(\mathrm{PO}_{4}{ }^{3-}\right)$ were analysed and observed parameters were compared with drinking water quality standards. In $\mathrm{GW}$ turbidity, $\mathrm{Mg}^{-} \mathrm{Cl}^{-}$and $\mathrm{Cd}_{\text {were }}$ not significantly different from the maximum permissible level $(\mathrm{p}>0.05)$ while SW has shown significant difference only for the turbidity $(\mathrm{p}>0.05)$. Both well and tank water samples from Thodamaduwa were polluted by Cd which exceeded the maximum permissible level standards. It was recorded as averages of $0.15,0.13$ and $0.019 \mathrm{ppb}$ for 3 identified polluted wells in GW and $0.01 \mathrm{ppb}$ in tank water. Accordingly the study it can be suggested that cumulative levels of heavy metals (such as Cd) may be aggravating the CKDu in the Northern Central Parts in Sri Lanka.
\end{abstract}

Key words: Chronic Kidney Disease of unknown aetiology, Surface water, Ground water, Drinking water quality, Drinking water quality standards

\section{Introduction}

The dry zone of Sri Lanka is well-known as the cradle of island's hydraulic civilization with the foremost kingdom, Anuradhapura. The adjustable environmental conditions with land availability in dry zone have become the key reasons to this agricultural extent throughout the area. Average annual rainfall in the dry zone is generally $1000 \mathrm{~mm}$ mostly from October to December and has a dry period from late May to September [Burt \& Weerasinghe, 2014]. The tank cascade system (TCS) is the most advanced water conveyance mechanism developed to overcome water scarcity problems in dry zone from the ancient irrigation history [Mahatantila et al., 2008]. Water in tanks is generally used for agricultural and domestic purposes including drinking [Jayawardena, 2015]. As TCS is a connected series of tanks organized within a micro catchment, the head water tank is principally nurtured from rainfall and river conversion while the irrigation channels distributing water through downstream [Bandara, 1985]. Tail end tank of TCS may significantly polluted as a result of intensive application of agrochemicals in paddy fields that were not evident in ancient time [Kumari et al., 2013]. As a result of polluted water intake, there is some health concerns reported from the people inhabited in the dry zone.
With reporting huge number of patients with a diseased kidney due to non-recognized reasons and by extending that statistic drastically during past two decades, the dry zone gained more advertence of government, public and private and academic organizations. It is been suggested that CKDu can be oriented through very long agricultural history of the dry zone as it is very common farmers or agricultural labourers.

Chronic Kidney Disease of unknown aetiology $(\mathrm{CKDu})$ is one of the greatest problem in north central province (NCP) which recorded highest mortality and morbidity rates and recognized reasons were unknown [Ratnayake et al., 2012, Noble et al., 2014]. CKDu is very aggressive disease with absence of certain responsible causes and very common among men (proportion of male: female is $3: 1$ ) who are in approximately the age of 40-60 years, and most of them are farmers or agricultural labourers. Dialysis or kidney transplant are the only medical solutions for this disease. The cost of dialysis of CKDu patients has become a severe problem on the government health authorities [Chandrajith et al., 2011a]. Consequently, nearly $80 \%$ of these patients ultimately die from kidney failure within the first two years [Misra \& Saxena, 2012].

During last two decades, mortality and morbidity rates have been increasing progressively, due to kid- 
Table 1: WHO (fourth edition) and SLS standards for drinking water

\begin{tabular}{|c|c|c|c|c|}
\hline Parameter & $\begin{array}{lr}\text { Maximum } & \text { per- } \\
\text { missible } & \text { level } \\
\text { WHO } & \text { Fourth } \\
\text { edition 2011) }\end{array}$ & $\begin{array}{lr}\text { Maximum } & \text { per- } \\
\text { missible } & \text { level } \\
\text { SLS (614: } 2013)\end{array}$ & $\begin{array}{l}\text { Maximum } \\
\text { missible } \\
\text { (Accepted) }\end{array}$ & $\begin{array}{l}\text { per- } \\
\text { level }\end{array}$ \\
\hline $\mathrm{pH}$ & $6.5-8.5$ & $6.5-8.5$ & - & \\
\hline Electrical Conductivity $(\mu \mathrm{S} / \mathrm{cm})$ & - & - & $1500^{*}$ & \\
\hline Total Dissolved solids (mg/L) & 600 & 500 & - & \\
\hline Turbidity NTU & - & 2 & 5 & \\
\hline Alkalinity $(\mathrm{mg} / \mathrm{L})$ & 500 & 200 & & \\
\hline Calcium (mg/L) & $100^{* *}$ & 100 & & \\
\hline Magnesium(mg/L) & 30 & 30 & & \\
\hline Sodium (mg/L) & 200 & 200 & & \\
\hline Chloride (mg/L) & 250 & 250 & & \\
\hline Phosphorus (mg/L) & 5 & 2 & & \\
\hline Nitrate Nitrogen $(\mathrm{mg} / \mathrm{L})$ & 50 & 50 & & \\
\hline Ammonium Nitrogen (mg/L) & 0.5 & 0.2 & & \\
\hline Sulphate (mg/L) & 250 & 250 & & \\
\hline Arsenic (mg/L) & 0.01 & 0.01 & & \\
\hline Cadmium (mg/L) & 0.003 & 0.003 & & \\
\hline Lead $(\mathrm{mg} / \mathrm{L})$ & 0.01 & 0.01 & & \\
\hline
\end{tabular}

*EC is not interpreted for drinking water in WHO or SLS standards. Hence the study used the standard value from http://www.google.lk/url?sa=t\&source=web\&rct=j\&url=http://mrccc.org.au/wp-content/uploads/2013/10/Water-Quality-SalinityStandards.pdf\&ved=0ahUKEwiqn9Xy-bTbAhVJhbwKHRfOCpoQFggkMAE\&usg=AOvVaw3GBXHTkDWptYNh3HeDHIxT

** Interpreted as Hardness of water in WHO fourth edition.

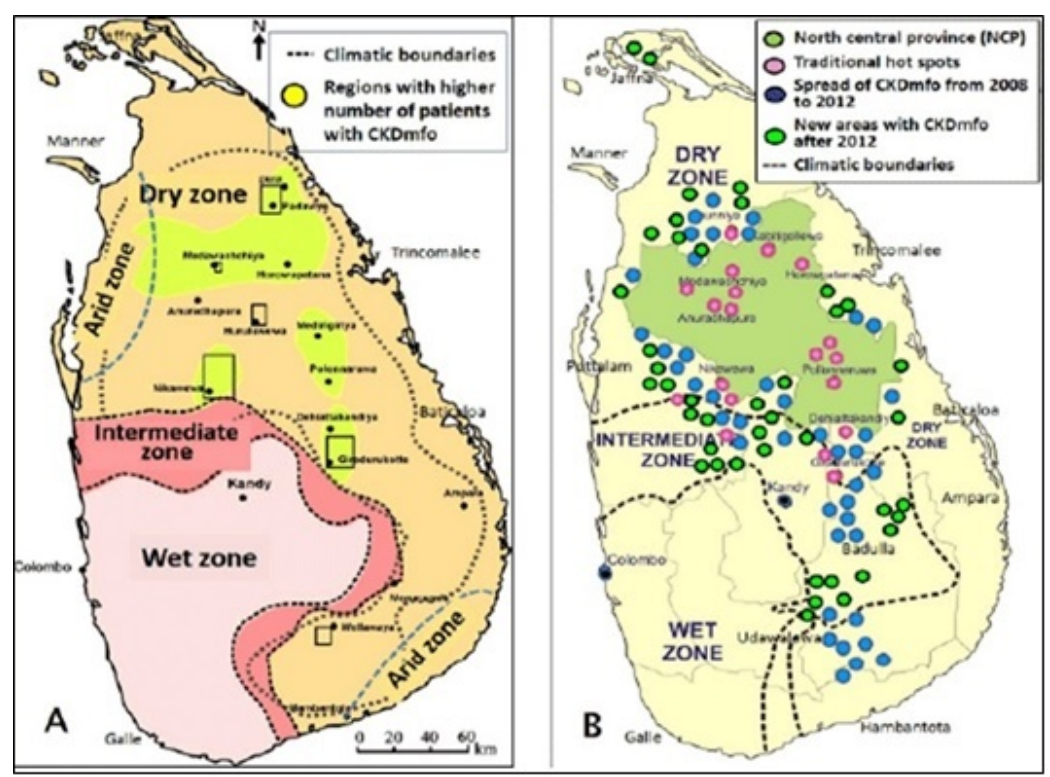

Figure 1: Prevalence of CKDu in Dry zone (1A: Regions where recorded patients with CKDu, 1B: Traditional hotspots and the spreading of CKDu with time. 
Table 2: Sampling locations for SW

\begin{tabular}{|c|c|}
\hline Tank No. & Name \\
\hline $\mathrm{T} 1$ & Thodamaduwa \\
\hline $\mathrm{T} 2 \mathrm{a}$ & Ulagalla \\
\hline $\mathrm{T} 2 \mathrm{~b}$ & Ulagallamahawewa \\
\hline T3 & Manakkulama \\
\hline $\mathrm{T} 4$ & Wagayakulama \\
\hline T5 & Karabayagama \\
\hline T6 & Pudukkulama \\
\hline $\mathrm{T} 7$ & Diwulwewa \\
\hline $\mathrm{T} 8$ & Periyakulama \\
\hline Т9 & Athiniwetunuwewa \\
\hline $\mathrm{T} 10$ & Ulankulama \\
\hline $\mathrm{T} 11$ & Itikattiya \\
\hline $\mathrm{T} 12$ & Ihalawewa \\
\hline $\mathrm{T} 13$ & KudaItikattiya \\
\hline $\mathrm{T} 14$ & Maradankadawala \\
\hline $\mathrm{T} 15$ & Halmillewa \\
\hline T16 & Settikulama \\
\hline $\mathrm{T} 17$ & Heenukgama \\
\hline $\mathrm{T} 18$ & Galwiharawewa \\
\hline T19 & Pahalawewa \\
\hline
\end{tabular}

ney related diseases in dry zone. Dry zone has been reported highest prevalence rates in North Central Province, Eastern Province and Uva province. When counting on the reasonable causes for $\mathrm{CKDu}$, several studies have proven that there should be a profound relationship between drinking water quality and CKDu [Wanigasuriya, 2012, Chandrajith et al., 2011a]. People from dry zone mainly acquire water from tanks and dug wells for agricultural issues for their domestic and agriculture purposes. Ulagalla is a small cascade that extended in Maradankadawala and Thirappane areas with 20 small tanks and 1100 farming families. They are acquiring drinking water from tanks/reservoirs (1\%), shallow dug wells (92\%) mostly as well as tube wells $(7 \%)$ in some circumstances [Jayasekara et al., 2013]. The population is vulnerable to unknown diseases as the area is being used for agricultural practices with heavy use of agrochemicals and fertilizer which is being transporting through those water resources for hundred years. So the water quality should be checked for the potential of CKDu of that area.

Ulagalla cascade is one of the prominent cascades in Anuradhapura district with twenty small tanks highly utilizing for agricultural purposes and still no any study has been conducted to evaluate water quality in the cascade with relevant to $\mathrm{CKDu}$. Hence the present study has been conducted to characterize the surface water (SW) and ground water $(\mathrm{GW})$ quality with $\mathrm{CKDu}$ in mentioned cascade. The aim of the study was to evaluate the GW and SW quality parameters and its subsequent comparison with World Health Organization, [WHO, 2011] and Sri Lankan Standards for potable water (SLS 614, 1983) related to CKDu in "Ulagalla Cascade" in Anuradhapura district, North Central Province, Sri Lanka.

Even if numerous studies have been conducted in Sri Lanka, the main responsible reason for CKDu is not yet identified. Hence many of the scientists and researchers have suggested number of certain risk factors where the CKDu-mfo (CKDu multi factorial 3 origin) term derived. CKDu-mfo described combination of two or more of risk factors and its synergistic effect could be accountable for CKDu [Wimalawansa, 2015]

Kidney disease with recognized causes are absent is named 'Chronic Kidney Disease of Unknown aetiology' (CKDu) and believing it is due to two or more factors, CKDumfo term is being using for this disease. Especially the areas such as Medawachchiya, Padaviya, Kebitigolawa, Medirigiriya (North Central Province), Nikawewa (North Western Province), Dehiattakandiya (Eastern Province) and Giradurukotte (Uva Province) were highlighted as threatened areas [De Silva et al., 2011]. Among two districts of NCP (Anuradhapura and Polonnaruwa) Anuradhapura has affected more and the disease is on the increase [Abeygun. \& Wick., 2014]. In 2012 the number of patients has further increased to 8000 [WHO, 2012]. In Anuradhapura District alone 18,000 cases of CKDu were reported with over 200 deaths recorded annually [Abeygun. \& Wick., 2014]. For Anuradhapura, Polonnaruwa and the whole country in 2007, CKD had been the $1^{\text {st }}, 2^{\text {nd }}$ and $9^{\text {th }}$ leading cause of death respectively [Fernando, 2011].

Figure 1 shows the prevalence of CKDu in Dry zone area, regions with highest number of patients and newly recognized hotspots of that critical issue. The affected area covers around $17,000 \mathrm{~km}^{2}$ and with a population of near 2.5 million in which over $95 \%$ live in rural areas [Wimalawansa, 2014].

Several risk factors were suggested during the last decade, to assume the occurrence and aetiology of the $\mathrm{CKDu}$ in the NCP [Wanigasuriya, 2012], but origin of the disease is still in problem and in the search [Gunatilake et al., 2014]. Causes such as overuse of pain killers, use of cheap aluminium cookware, habit of illegal drugs and alcohol, leptospirosis, smoking, petrochemical contamination, unsafe working conditions, longterm consumption of contaminated water and food, genetic susceptibility, lack of safety measures when using agrochemicals, Ayurveda medicines, and previous inci- 
Table 3: Monitored water quality parameters and methods of analysis

\begin{tabular}{ll}
\hline Parameter & Method of analysis \\
\hline pH and Electrical Conductivity (EC) & Multi parameter analyser (HACHHQ40d) \\
Total Dissolved Solids (TDS) & Multi parameter analyser (EUTECH PCD650) \\
$\mathrm{Na}^{+}, \mathrm{K}^{+}, \mathrm{Mg}^{2+}, \mathrm{Ca}^{2+}, \mathrm{As}^{3+}, \mathrm{Pb}^{2+}, \mathrm{Cd}^{2+}$ & ICP-OES(Thermo ICAP 7400) \\
Ammonium nitrogen & 4500NH F phenate method(APHA 1998) \\
Nitrate nitrogen & Salicylic acid method(APHA 1998) \\
Alkalinity & Acid base titration(APHA 1998) \\
Phosphate & Ascorbic acid method (APHA 1998) \\
Turbidity & Turbid meter (EUTECH TN-100) \\
\hline
\end{tabular}

dents of snake bites were reported [Wanigasuriya, 2012, Wimalawansa, 2014]. Harmful agricultural practises, including excessive and indiscriminate use of toxic agrochemicals (fertilizers, pesticides, and weedicides), lack of safety measures when using agrochemicals, intake of contaminated water from paddy fields and from contaminated ground water wells, have led to the increase of this widespread disease in NCP [Wimalawansa, 2014, Chandrajith et al., 2011a, Chandrajith et al., 2011b, Daily mirror, 2013]. Regardless of this deadly disease, many farmers in NCP practised to use excessive amounts of agrochemicals long term to get higher yields [Wimalawansa, 2014]. Hardness or high amount of fluoride in water, use of cheap aluminium cookware, ionicity in drinking water are suggested as multi factorial causes for this disease [Kumari et al., 2016]. Among these factors drinking water related factors were discussed and argued by literature .

Drinking water quality parameters are apparently related with the occurrence of the CKDu [Kumari et al., 2016, Abeygun. \& Wick., 2014]. Most of the agrochemicals (weedicides, insecticides, and fungicides) contain very high concentrations of Cadmium $\left(\mathrm{Cd}^{2+}\right)$, Arsenic $\left(\mathrm{As}^{3+}\right)$ and other heavy metallic substances [Keil, 2011, Illeperuma, 2000]. Through the studied which have been conducted in dry zone, Sri Lanka, $\mathrm{Cd}^{2+}$ and $\mathrm{As}^{3+}$ were supposed as risk factors for CKDu [Mendis, 2011]. Drinking water and rice contaminated with $\mathrm{As}^{3+}$ has been identified as the key motives for CKDu and through the theory, $\mathrm{As}^{3+}$ is being bio-accumulating in human bodies [Dharmawardana et al., 2015]. Water hardness plays a great role to support heavy metals by cation exchange capacity while fertilizer runoff has increased the ionicity of ground water (Wanigasuriya, 2012). Toxins ingested from food and water, direct absorption of toxins due to uncaring management of agrochemicals, extended exposure to toxins and pollutants from drinking water are assumed as most reasonable risk factors [Dharmawardana et al., 2015] .
The quality of drinking water is powerful environmental factor that determine the health of human. Therefore, the WHO and various national agencies have introduced drinking water quality standards that specify the permissible chemical, microbial and radiological characteristics of safe water (Table 1). Major drinking water sources of NCP people are $92 \%$ shallow dug wells, $7 \%$ tube wells, $1 \%$ reservoirs [Jayasekara et al., 2013]. Most of the tested drinking water quality parameters are higher than the WHO recommended levels in NCP. However, within the NCP, small compartments of $\mathrm{CKDu}$ non-prevalence sectors also exists [Wanigasuriya, 2012].

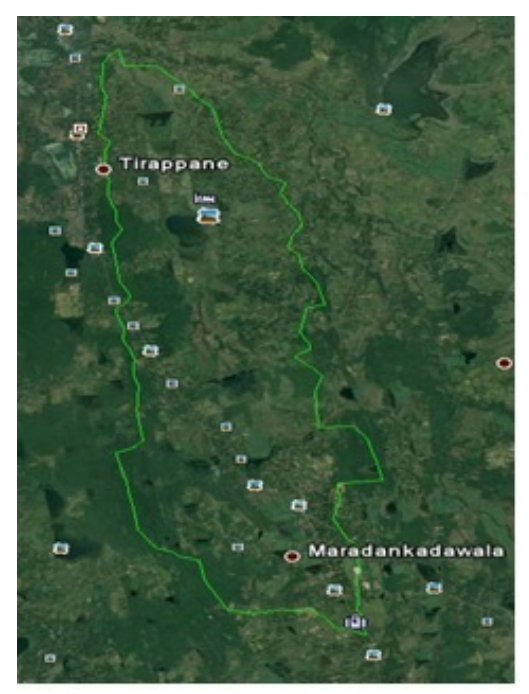

Figure 2: Study Area-Ulagalla cascade

\section{Methods}

Ulagalla cascade is a prominent cascade located in Anuradhapura district with twenty small tanks and highly utilizing for agricultural purposes [Kumudumali et al., 2016]. It is located in DL1b agroecological region (Dry zone Low country) of Sri Lanka. Total number of farm families living in the study area was approximately 1100 and the total land area is about 


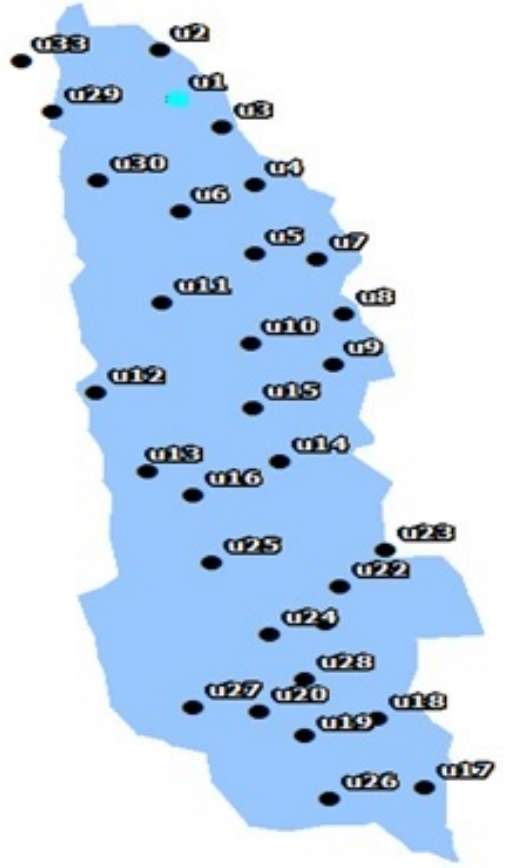

Figure 3: Sampling locations for ground water

$25 \mathrm{~km}^{2}$. Maradankadawala and Thirappane (figure 2), areas of Ulagalla cascade were selected for the sampling locations for both GW and SW.

Water samples were collected from all the 20 tanks (Table 2) for SW (T) and randomly selected 30 GW wells (Figure3) for ground water (U) in Ulagalla cascade in Anuradhapura.

The total area of the cascade was divided into $1 \mathrm{~km}^{2}$ grids and one well to represent each grid was purposely selected from above mentioned villages to evaluate the quality of GW (thirty wells located in uplands). Availability of GW was assessed by measuring the depth to GW and the depth of well from the surface during three months of period.

The water samples were transferred into $250 \mathrm{~mL}$ clean polyethylene bottles after rinsing three times with the water to be sampled and labelled. Two water samples were collected from each sampling points once a month during three months (July, August and September). These bottles were tightly closed, labelled and transported to the Laboratory of soil and water science, Department of Agricultural Engineering and Soil Science, Faculty of Agriculture, Rajarata University of Sri Lanka. All the samples were stored below 40C temperature in a refrigerator.

All the water samples were filtered by using number 01 Whatman filter papers for further chemical analysis to evaluate all the cations, anions and heavy metals. Samples were stored below 40C and Table 3 shows the analysis methods for selected water quality parameters.

Geographical Information System (GIS) has been used for the study as a tool for storing, analysing and displaying spatial data. Once the input data was imported as a point layer into ArcGIS 10.1, geo-database was created to generate the maps of spatial distribution of selected ground water quality parameters. Interpolation is the process of predicting unknown values using the known values in the vicinity. Point based Inverse Distance Weighted (IDW) interpolation method was used to produce spatial distribution of GW quality variables. GIS is helpful to developing solutions for water resources problems for assessing water quality, determining water availability, preventing flooding, understanding the natural environment and mapping water resources on local or regional scale [Ferry et al., 2003].

To evaluate measured drinking water quality parameters of GW and SW t test (one sample t test and two sample t test) was performed by using Minitab statistical software package.

\section{Results and Discussion}

Water quality parameters have been tested for both GW and SW in the Ulagalla cascade and recorded in Table 4. Obtained results had been comparatively discussed with the results obtained from previous studies to the dry zone by analysing same parameters in Kumari et al. (2016) and Chandarjith et al. (2011b). pH in GW has varied between the range of $\mathrm{pH} 6.7 \quad 8.7$ and in the SW it was 5.8-8.2. When compared with the drinking water quality guideline values [SLS 614, 2013, WHO, 2011] $96.66 \%$ of GW wells and all the SW bodies (100\%) were below the maximum permissible level, yet suitable for drinking purpose. Significant difference from one sample t test was observed for GW and SW $(\mathrm{p}<0.05)$.

Electrical Conductivity (EC) in drinking water is related to the presence of water salinity and ion (both cations and anions) content. Water hardness can be the reason for highest $\mathrm{EC}$ in water. $\mathrm{EC}$ in $\mathrm{GW}$ has varied from $427.10 \mu \mathrm{S} / \mathrm{cm}$ to $2590.67 \mu \mathrm{S} / \mathrm{cm}$ and $\mathrm{EC}$ of $\mathrm{SW}$ has varied from $94.25 \mu \mathrm{S} / \mathrm{cm}$ to $806.33 \mu \mathrm{S} / \mathrm{cm}$ in Ulagalla cascade. Based on world accepted standards for EC, $16.66 \%$ of GW wells and none of SW tanks were exceeded the maximum permissible level, then not suitable for drinking purpose. Obtained p values for one sample t-test of the recorded p value and SLS standards were 0 for both GW and SW. Kumari et al. (2016) reported the highest average EC values of GW in CKDu non prevalent areas. According to the Kumari et al. (2016) EC in $\mathrm{GW}$ were varied from $131.4 \mu \mathrm{S} / \mathrm{cm}$ to $556 \mu \mathrm{S} / \mathrm{cm}$ in dry zone. Their maximum EC value of GW was below than the maximum EC value of GW in Ulagalla cascade. Chandarjith et al. (2011b) were documented highest average GW EC value as $3400 \mu \mathrm{S} / \mathrm{cm}$ thus, that value was comparatively higher than the average GW EC of Ulagalla cascade. According to the Kumari et al. (2016) average EC of SW was varied from $96.2 \mu \mathrm{S} / \mathrm{cm}$ to 299.0 $\mu \mathrm{S} / \mathrm{cm}$.

Water has the ability to dissolve a wide range of in- 
Table 4: Recorded values for each parameter

\begin{tabular}{|c|c|c|c|c|c|c|}
\hline Parameter & $\begin{array}{l}\text { Observed } \\
\text { values } \\
(\mathrm{GW})\end{array}$ & $\begin{array}{l}\text { Observed } \\
\text { values } \\
(\mathrm{SW})\end{array}$ & $\begin{array}{l}\text { Maximum } \\
\text { permis- } \\
\text { sible } \\
\text { level(MPL) } \\
\text { for } \\
\text { drinking } \\
\text { water } \\
\text { (WHO, } \\
\text { 4t } h \text { edi- } \\
\text { tion) }\end{array}$ & $\begin{array}{l}\text { MPL for } \\
\text { drinking } \\
\text { wa- } \\
\text { ter (SLS } \\
\text { 614:2013) }\end{array}$ & $\begin{array}{l}\text { Wells } \\
\text { that } \\
\text { recorded } \\
\text { as not } \\
\text { suitable } \\
\text { for use }\end{array}$ & $\begin{array}{l}\text { Tanks } \\
\text { that } \\
\text { recorded } \\
\text { as not } \\
\text { suitable } \\
\text { for use }\end{array}$ \\
\hline $\mathrm{SO}_{4}{ }^{2-}$ & 1.3370 & 116 & 250 & 250 & $\begin{array}{l}\text { All wells } \\
\text { were be- } \\
\text { low the } \\
\text { MPL } \\
\text { (Highest } \\
\text { U13) }\end{array}$ & $\begin{array}{l}\text { All tanks } \\
\text { were be- } \\
\text { low the } \\
\text { MPL } \\
\text { (Highest } \\
\text { T3) }\end{array}$ \\
\hline $\mathrm{As}^{3+}$ & 0.030 .44 & 0.020 .19 & 10 & 10 & $\begin{array}{l}\text { All wells } \\
\text { were be- } \\
\text { low the } \\
\text { MPL } \\
\text { (Highest } \\
\text { U1) }\end{array}$ & $\begin{array}{l}\text { All tanks } \\
\text { were be- } \\
\text { low the } \\
\text { MPL } \\
\text { (Highest } \\
\text { T12) }\end{array}$ \\
\hline $\mathrm{Pb}^{3+}$ & 1.768 .85 & 0.592 .8 & 10 & 10 & $\begin{array}{l}\text { All wells } \\
\text { were be- } \\
\text { low the } \\
\text { MPL } \\
\text { (Highest } \\
\text { U13) }\end{array}$ & $\begin{array}{l}\text { All tanks } \\
\text { were be- } \\
\text { low the } \\
\text { MPL } \\
\text { (Highest } \\
\text { T5) }\end{array}$ \\
\hline $\mathrm{Cd}^{2+}$ & $\begin{array}{l}\text { U180.15; } \\
\text { U190.13; } \\
\text { U200.01 }\end{array}$ & $\mathrm{T} 10.01$ & 3 & 3 & $\begin{array}{l}\text { All wells } \\
\text { were be- } \\
\text { low the } \\
\text { MPL, } \\
\text { however } \\
\text { U18, U19 } \\
\& \quad \text { U20 } \\
\text { have re- } \\
\text { ported } \\
\text { Cd. }\end{array}$ & $\begin{array}{l}\text { All tanks } \\
\text { were be- } \\
\text { low the } \\
\text { MPL, } \\
\text { however } \\
\text { T1 has } \\
\text { reported } \\
\text { Cd. }\end{array}$ \\
\hline $\mathrm{PO}_{4}{ }^{3-}$ & 0.181 .05 & 0.080 .18 & 5 & 2 & $\begin{array}{lr}\text { All wells } \\
\text { were be- } \\
\text { low the } \\
\text { MPL }\end{array}$ & $\begin{array}{lr}\text { All tanks } \\
\text { were be- } \\
\text { low the } \\
\text { MPL }\end{array}$ \\
\hline Alkalinity & 33.33162 .5 & 10.4270 .83 & 200 & 200 & $\begin{array}{lr}\text { All wells } \\
\text { were be- } \\
\text { low the } \\
\text { MPL }\end{array}$ & $\begin{array}{ll}\text { All tanks } \\
\text { were be- } \\
\text { low the } \\
\text { MPL }\end{array}$ \\
\hline $\mathrm{NO}_{3}{ }^{-} \mathrm{N}$ & 0.078 .35 & 0.121 .97 & 10 & 50 & $\begin{array}{l}\text { All wells } \\
\text { were be- } \\
\text { low the } \\
\text { MPL } \\
\text { (Highest } \\
\text { U17) }\end{array}$ & $\begin{array}{l}\text { All tanks } \\
\text { were be- } \\
\text { low the } \\
\text { MPL } \\
\text { (Highest } \\
\text { T19) }\end{array}$ \\
\hline $\mathrm{NH}_{4}{ }^{+}-\mathrm{N}$ & 0.070 .13 & 0.070 .24 & 0.5 & 0.2 & $\begin{array}{l}\text { All wells } \\
\text { were be- } \\
\text { low the } \\
\text { MPL } \\
\text { (Highest } \\
\text { U6) }\end{array}$ & $\begin{array}{l}\text { All tanks } \\
\text { were be- } \\
\text { low the } \\
\text { MPL } \\
\text { (Highest } \\
\text { T19) }\end{array}$ \\
\hline
\end{tabular}




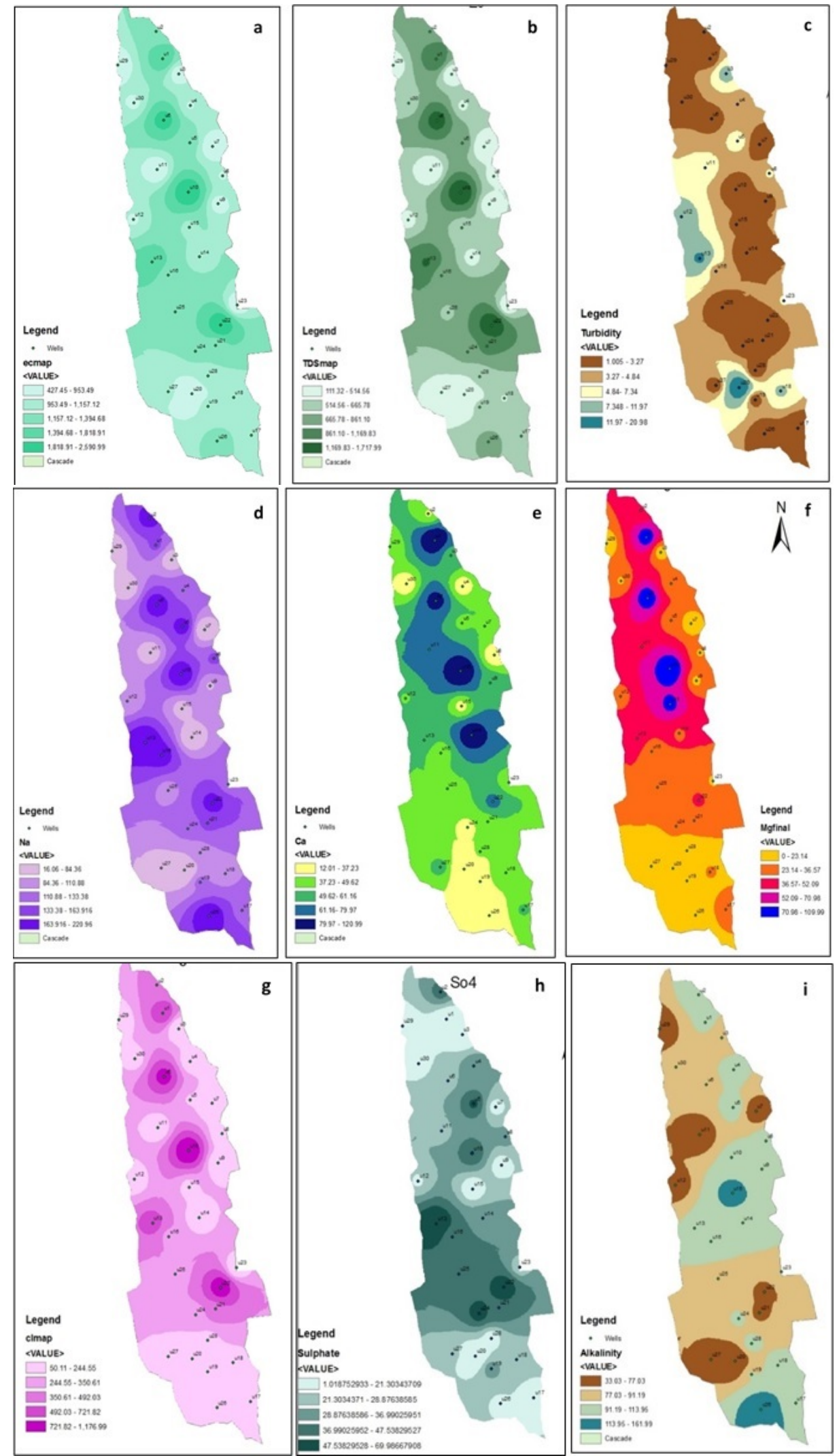

Figure 4: Spatial distribution of several parameters of GW in Ulagalla cascade. a-EC variation, b- TDS, cTurbidity, $\mathrm{d}-\mathrm{Na}^{+}, \mathrm{e}=\mathrm{Ca}^{2+}, \mathrm{f}=\mathrm{Mg}^{2+}, \mathrm{g}=\mathrm{Cl}^{-}, \mathrm{h}=\mathrm{SO}_{4}{ }^{2-}, \mathrm{i}=$ Alkalinity

organic and some organic minerals or salts such as $\mathrm{K}^{+}$, $\mathrm{Ca}^{2+}, \mathrm{Na}^{+}, \mathrm{HCO}_{3}^{-}, \mathrm{Cl}^{-}, \mathrm{Mg}^{2+}, \mathrm{SO}_{4}{ }^{2-}$ etc. These minerals produced undesirable taste and diluted colour in the appearance of water. In Ulagalla cascade average TDS values of GW was varied from $111.43 \mathrm{mg} / \mathrm{L}$ to $1718.33 \mathrm{mg} / \mathrm{L}$. According to the drinking water stan- 
dards, $43.33 \%$ wells were exceeding the MPL while $60 \%$ of wells including U10 (highest), U1, U6, U13 and U22 exceeding MPL for SLS standards. According to the $\mathrm{Ku}-$ mari et al. (2016) from a different previous study for same catchment, TDS in GW was varied from $65.9 \mathrm{mg} / \mathrm{L}$ to $311 \mathrm{mg} / \mathrm{L}$ and average TDS in SW was varied from $40.2 \mathrm{mg} / \mathrm{L}$ to $141.53 \mathrm{mg} / \mathrm{L}$. The maximum TDS values reported in Kumari et al. (2016) were below than the maximum TDS values of our study for GW and SW in Ulagalla cascade. According to their study all the sampling locations were below the safe limit thus, suitable for drinking purpose. Therefore, these results were not accordance with the present results from our study for Ulagalla cascade. In Ulagalla cascade significant difference $(\mathrm{GWp}=0.026$ and $\mathrm{SWp}=0)$ has observed between GW and SW $(\mathrm{p}<0.05)$.

Turbidity is the relative clarity of the water that reduces the transmission of light. Turbidity of GW in Ulagalla cascade was varied from $0.92 \mathrm{NTU}$ to $20.85 \mathrm{NTU}$ and in the SW it was varied from 1.62 NTU to 313.19 NTU ( $p$ for $\mathrm{GW}=0.305$ and $\mathrm{p}$ for $\mathrm{SW}=0.063$ for SLS standards, 2 NTU). According to the SLS drinking water quality guideline value $50 \%$ of $\mathrm{GW}$ locations and $95 \%$ of SW tanks were exceeded the maximum turbidity level. Based on world acceptable laboratory guideline values $26.67 \%$ of GW locations and $53.33 \%$ of SW tanks were exceeded the maximum permissible turbidity level. Thus, doubtful for drinking purpose. Significant difference was not observed between GW and SW.

In Ulagalla cascade, observed $\mathrm{Na}^{+}$concentration was varied from $16.42 \mathrm{mg} / \mathrm{L}$ to $221.41 \mathrm{mg} / \mathrm{L}$ in $\mathrm{GW}$ and from $7.51 \mathrm{mg} / \mathrm{L}$ to $81.54 \mathrm{mg} / \mathrm{L}$ in $\mathrm{SW}$. Based on the WHO and SLS guideline values $13.33 \%$ of GW locations were exceeded maximum permissible $\mathrm{Na}^{+}$value while all the SW locations were below the safe limit. In Ulagalla cascade highest average $\mathrm{Na}^{+}$concentration was noted in GW while lowest average $\mathrm{Na}^{+}$concentration has recorded in SW. There was a significant difference between standards and observed values of GW and $\mathrm{SW}(\mathrm{p}<0.05)$ as $\mathrm{p}$ for $\mathrm{GW}=0$ and $\mathrm{p}$ for $\mathrm{SW}=0)$. According to the Kumari et al. (2016) average $\mathrm{Na}^{+}$concentration in GW was varied from $11.39 \mathrm{mg} / \mathrm{L}$ to 38.18 $\mathrm{mg} / \mathrm{L}$. Highest $\mathrm{Na}^{+}$concentration value of their study was almost less than the average $\mathrm{Na}^{+}$concentration in Ulagalla cascade. Thus this result was not accordance with Kumari et al. (2016). Chandrajith et al. (2011b) has been reported $1910 \mathrm{mg} / \mathrm{L}$ in their study. It was almost higher than the average $\mathrm{Na}^{+}$concentration of GW in Ulagalla cascade. According to the Kumari et al. (2016) average $\mathrm{Na}^{+}$concentration in $\mathrm{SW}$ was varied from $10.54 \mathrm{mg} / \mathrm{L}$ to $27.85 \mathrm{mg} / \mathrm{L}$ in their study. It is almost lower than the average $\mathrm{Na}^{+}$concentration in $\mathrm{SW}$ of Ulagalla cascade.

Ca ions (along with $\mathrm{Mg}$ ions) create the hardness of water, though no health-based guideline standards are interpreted for drinking water. However, the public acceptance for hardness is $100-300 \mathrm{mg} / \mathrm{L}$ and gener- ally accepted as $100 \mathrm{mg} / \mathrm{L}$ by considering other dependable factors such as pH and alkalinity [WHO, 2011]. The $\mathrm{Ca}^{2+}$ concentration in GW of Ulagalla cascade was varied from $12.27 \mathrm{mg} / \mathrm{L}$ to $120.76 \mathrm{mg} / \mathrm{L}$ (average $=50.49$ $\mathrm{mg} / \mathrm{L}$ ) and in $\mathrm{SW} \mathrm{Ca}^{2+}$ concentration was varied from $8.86 \mathrm{mg} / \mathrm{L}$ to $41.25 \mathrm{mg} / \mathrm{L}$ (average $=25.68 \mathrm{mg} / \mathrm{L})$. According to SLS guideline value, $10 \%$ of GW locations and based on the WHO guideline, $13.34 \%$ of GW locations were exceeded the maximum permissible levels respectively ( $\mathrm{p}$ for $\mathrm{GW}=0$ and $\mathrm{p}$ for $\mathrm{SW}=0$ ). There was a significant difference between GW and SW $(\mathrm{p}<0.05)$. According to the Kumari et al. (2016) $\mathrm{Ca}^{2+}$ concentration in GW of their study was varied from $10.3 \mathrm{mg} / \mathrm{L}$ to $30.54 \mathrm{mg} / \mathrm{L}$. That value was lower than the observed values in Ulagalla cascade. In addition, they have recorded high $\mathrm{Ca}^{2+}$ concentration in the GW of CKDu non prevalent areas. Based on the both SLS and WHO guideline value, all the SW bodies were below the maximum permissible $\mathrm{Ca}^{2+}$ concentration level hence, suitable for drinking purpose. According to the Kumari et al. (2016) $\mathrm{Ca}^{2+}$ concentrations was varied from $9.12 \mathrm{mg} / \mathrm{L}$ to 30.79 $\mathrm{mg} / \mathrm{L}$. Maximum average $\mathrm{Ca}^{2+}$ a concentration of their study was lower than the maximum average $\mathrm{Ca}^{2+}$ concentration value of Ulagalla cascade.

$\mathrm{Mg}^{2+}$ concentration in GW of Ulagalla cascade was varied from $2.9 \mathrm{mg} / \mathrm{L}$ to $110.05 \mathrm{mg} / \mathrm{L}$. Based on the observed values $33.33 \%$ of GW were exceeded the WHO and SLS maximum permissible levels ( $\mathrm{p}$ for $\mathrm{GW}=0.468$ and $\mathrm{p}$ for $\mathrm{SW}=0)$. According to the Kumari et al. (2016) $\mathrm{Mg}^{2+}$ concentration in GW locations of their study was varied from $2.63 \mathrm{mg} / \mathrm{L}$ to $23.43 \mathrm{mg} / \mathrm{L}$. These values were lower than the maximum $\mathrm{Mg}^{2+}$ concentration value of Ulagalla cascade. Furthermore, Chandrajith et al. (2011b) has recorded average $\mathrm{Mg}^{2+}$ concentration in GW of their study as $1280 \mathrm{mg} / \mathrm{L}$ and it was very higher than the Ulagalla cascade value. In the SW of Ulagalla cascade $\mathrm{Mg}^{2+}$ concentration was varied from $1.39 \mathrm{mg} / \mathrm{L}$ to $23.55 \mathrm{mg} / \mathrm{L}$. Based on the SLS and WHO guideline values all the sources were below than the maximum level hence all were suitable for drinking. According to Kumari et al. (2016), $\mathrm{Mg}^{2+}$ concentration in GW locations of their study was varied from $2.95 \mathrm{mg} / \mathrm{L}$ $14.98 \mathrm{mg} / \mathrm{L}$. These values were lower than the maximum $\mathrm{Mg}^{2+}$ concentration value of Ulagalla cascade.

$\mathrm{Cl}^{-}$concentration in GW of Ulagalla cascade was varied from $50 \mathrm{mg} / \mathrm{L}$ to $1176.67 \mathrm{mg} / \mathrm{L}$. Based on the guideline values $33.33 \%$ of GW locations were exceeded safe limit. According to the Kumari et al. (2016) $\mathrm{Cl}^{-}$concentration in GW of their study was varied from $15 \mathrm{mg} / \mathrm{L}$ to $53.33 \mathrm{mg} / \mathrm{L}$. These values were lower than the highest $\mathrm{Cl}^{-}$concentration value in GW of Ulagalla cascade (p for $\mathrm{GW}=0.411$ and $\mathrm{p}$ for $\mathrm{SW}=0$ ). Also Chandrajith et al. (2011b) were recorded the average $\mathrm{Cl}^{-}$concentration in $\mathrm{GW}$ of their study was $688 \mathrm{mg} / \mathrm{L}$. $\mathrm{Cl}^{-}$concentration in SW was varied from $20 \mathrm{mg} / \mathrm{L}$ to $280 \mathrm{mg} / \mathrm{L} .5 \%$ of SW locations were exceeded the safe limit. Kumari et al. (2016) have reported the $\mathrm{Cl}^{-}$concentration in SW was varied from $13.33 \mathrm{mg} / \mathrm{L}$ to $25.0 \mathrm{mg} / \mathrm{L}$ respectively. 
These values were almost lower than the average $\mathrm{Cl}^{-}$ concentration values of Ulagalla cascade. There was a significant difference between GW and SW $(\mathrm{p}<0.05)$.

$\mathrm{SO}_{4}{ }^{2-}$ concentration in $\mathrm{GW}$ of Ulagalla cascade was varied from $1.33 \mathrm{mg} / \mathrm{L}$ to $70 \mathrm{mg} / \mathrm{L}$ and $\mathrm{SO}_{4}{ }^{2-}$ concentration in $\mathrm{SW}$ of Ulagalla cascade was varied from $1 \mathrm{mg} / \mathrm{L}$ to $16 \mathrm{mg} / \mathrm{L}$ ( $\mathrm{p}$ for $\mathrm{GW}=0$ and $\mathrm{p}$ for $\mathrm{SW}=0)$. In Ulagalla cascade $\mathrm{PO}_{4}{ }^{3-}$ concentration in $\mathrm{GW}$ was varied from $0.18 \mathrm{mg} / \mathrm{L}$ to $1.05 \mathrm{mg} / \mathrm{L}$ and $\mathrm{PO}_{4}{ }^{3-}$ concentration in $\mathrm{GW}$ was varied from 0.08 $\mathrm{mg} / \mathrm{L}$ to $0.18 \mathrm{mg} / \mathrm{L}$. There was a significant difference between standards and observed values of GW and SW $(\mathrm{p}<0.05)$ as $\mathrm{p}$ for $\mathrm{GW}$ was 0 and $\mathrm{p}$ value for $\mathrm{SW}$ was 0 . Alkalinity in GW was varied from $33.33 \mathrm{mg} / \mathrm{L}$ to $162.5 \mathrm{mg} / \mathrm{L}$, while the average alkalinity in SW was varied from $10.42 \mathrm{mg} / \mathrm{L}$ to $70.83 \mathrm{mg} / \mathrm{L}$ ( $\mathrm{p}$ for $\mathrm{GW}=0$ and $\mathrm{p}$ for $\mathrm{SW}=0$ ). Based both guideline values, all the GW locations and SW bodies were below the maximum permissible levels of $\mathrm{SO}_{4}{ }^{-} 2, \mathrm{PO}_{4}{ }^{3-}$ and alkalinity. There was a significant difference between $\mathrm{GW}$ and $\mathrm{SW}$ $(\mathrm{p}<0.05)$ for $\mathrm{SO}_{4}{ }^{-} 2, \mathrm{PO}_{4}{ }^{3-}$ and alkalinity respectively.

Observed $\mathrm{NH}_{4}{ }^{+}-\mathrm{N}$ concentration in $\mathrm{GW}$ was varied from $0.07 \mathrm{mg} / \mathrm{L}$ and $0.13 \mathrm{mg} / \mathrm{L}$ and in the $\mathrm{SW}$ it was varied from $0.07 \mathrm{mg} / \mathrm{L}$ to $0.24 \mathrm{mg} / \mathrm{L}$ (p for $\mathrm{GW}=0$ and $\mathrm{p}$ for $\mathrm{SW}=0$ ) in the Ulagalla cascade while the average $\mathrm{NO}_{3}{ }^{-}-\mathrm{N}$ concentrations of $\mathrm{GW}$ was varied from 0.07 $\mathrm{mg} / \mathrm{L}$ to $8.35 \mathrm{mg} / \mathrm{L}$ and average $\mathrm{NO}_{3}{ }^{-}{ }^{-} \mathrm{N}$ concentrations of SW was varied from $0.12 \mathrm{mg} / \mathrm{L}$ to $1.97 \mathrm{mg} / \mathrm{L}$ (p for $\mathrm{GW}=0$ and $\mathrm{p}$ for $\mathrm{SW}=0$ ). Based on the WHO and SLS guideline values all the GW locations and SW bodies were below the maximum permissible levels of $\mathrm{NH}_{4}{ }^{+}-\mathrm{N}$ and $\mathrm{NO}_{3}{ }^{-}-\mathrm{N}$.

$\mathrm{Pb}^{2+}$ concentration in GW of Ulagalla cascade was varied from $1.76 \mu \mathrm{g} / \mathrm{L}$ and $8.85 \mu \mathrm{g} / \mathrm{L}$ and $\mathrm{Pb}^{2+}$ concentration in SW of Ulagalla cascade was varied from $0.59 \mu \mathrm{g} / \mathrm{L}$ and $2.80 \mu \mathrm{g} / \mathrm{L}$ (p for $\mathrm{GW}=0$ and $\mathrm{p}$ for $\mathrm{SW}=$ $0)$. All the GW and SW locations were below the maximum permissible levels of SLS and WHO drinking water quality guideline values. Chandrajith et al. (2011a) have observed $0.957 \mu \mathrm{g} / \mathrm{L}$ of average $\mathrm{Pb}$ concentration in their study. $\mathrm{Pb}^{2+}$ concentrations in Ulagalla cascade were higher than that literature results. Surface and groundwater contamination by $\mathrm{Pb}^{2+}$ can be happened due to excessive use of agrochemicals [Katz et al., 1999]. In some fertilizers and weedicides that have been using in agriculture, reported maximum dangerous levels of $\mathrm{Cd}^{2+}, \mathrm{As}^{3+}$ and $\mathrm{Pb}^{2+}$. Ulagalla cascade area is a highly agriculture area and ensured for using those agrochemicals for higher harvest. In addition, it is important to mention that As and $\mathrm{Cd}$ excretion in urine were significantly higher in healthy people living in the $\mathrm{CKDu}$ endemic area however, $\mathrm{Pb}^{2+}$ was significantly lower [WHO, 2012]. However, it can concentrate in human tissues and bones through bio-accumulation.

In Ulagalla cascade $\mathrm{Cd}^{2+}$ has detected in three wells (U18, U19 and U20) and one SW tank T1 (Thodamaduwa). $\mathrm{Cd}^{2+}$ concentrations of these water bodies were $0.15 \mu \mathrm{g} / \mathrm{L}, 0.13 \mu \mathrm{g} / \mathrm{L}$ and $0.01 \mu \mathrm{g} / \mathrm{L}$ in U18, U19 and $\mathrm{U} 20$ respectively. In $\mathrm{T} 1$ tank average $\mathrm{Cd}^{2+}$ concentration was $0.01 \mu \mathrm{g} / \mathrm{L}$. All these observed values were below the maximum permissible guideline values. One sample t test results were given as $\mathrm{p}$ value for $\mathrm{GW}$ was 0.285 and $\mathrm{p}$ value for $\mathrm{SW}$ was 0 .

$\mathrm{As}^{3+}$ concentration in GW in Ulagalla cascade was varied from $0.03 \mu \mathrm{g} / \mathrm{L}$ and $0.44 \mu \mathrm{g} / \mathrm{L}$ and $\mathrm{As}^{3+}$ concentration in GW and SW in Ulagalla cascade was varied from $0.02 \mu \mathrm{g} / \mathrm{L}$ and $0.19 \mu \mathrm{g} / \mathrm{L}$ ( $\mathrm{p}$ for $\mathrm{GW}=0$ and $\mathrm{p}$ for $\mathrm{SW}=0)$. All the sources were below the maximum permissible level of SLS and WHO drinking water quality guidelines. There was no significant difference of the $\mathrm{As}^{3+}$ concentration between GW and SW. Long term ingestion of arsenic contaminated drinking water may effect to peripheral vascular diseases and to peripheral nervous system (Gunathilake et al. 2014). Jayasumana et al. (2011) has strongly argued that $\mathrm{As}^{3+}$ in pesticides can be combined with the hardness in water to form the calcium arsenate and when calcium arsenate transported to kidneys, it can cause severe kidney damages. Wasana et al. (2016) have suggested total $\mathrm{As}^{3+}$ in water cannot be considered as the causative factor for the incidence of CKDu though they have observed As levels below the maximum permissible levels of SLS and WHO guidelines.

Observed measurements were graphically analysed by using ArcGIS and the GIS maps were prepared for spatial distribution of water quality parameters. Figure 4 will represent those GIS maps for each parameter throughout the area.

\section{References}

Abeygunasekera, A. \& Wickremasinghe, T. (2014) Short term measures to control chronic kidney disease of uncertain aetiology (CKDu). pp.110.

Bandara, C.M.M. (1985). Catchment Ecosystem and Village Tank Cascades in the Dry Zone of Sri Lanka: A Time Tested System of Land and Water Resource Management. Strategies for river basin management, pp.99-113.

DOI:http://dx.doi.org/10.1007/978-94-009-54588_11

Burt,T.P. \& Weerasinghe, K.D.N. (2014) Rainfall distributions in Sri Lanka in Time and space: An analysis based on daily rainfall data. Climate 2014, 2, pp.242-263;

DOI:https://doi.org/10.3390/cli2040242

Chandrajith, R., Dissanayake, C. B., Ariyarathna, T., Herath, H. M. J. M. K. \& Padmasiri, J. P. (2011a) Dose-dependent $\mathrm{Na}$ and $\mathrm{Ca}$ in fluoride-rich drinking water- Another major cause of chronic renal failure in tropical arid regions. Science of The Total Environment, 409, pp.671-675. 
DOI:https://doi.org/10.1016/j.scitotenv.2010.10. 046

Chandrajith, R., Nanayakkara, S., Itai, K., Aturaliya, T. N. C., Dissanayake, C. B., Abeysekera, T. \& Koizumi, A. (2011b) Chronic kidney diseases of uncertain etiology (CKDue) in Sri Lanka: Geographic distribution and environmental implications. Environmental Geochemistry and Health, $33(3)$, pp.267278.

DOI:https://doi.org/10.1007/s10653-010-9339-1

Daily mirror (2013). Agro-chemicals; The silent killer in Sri Lanka 2013-07-29.

URL:www.dailymirror.lk/article/agro-chemicalsthe-silent-killer-in-sri-lanka-33018.html

De Silva, N., Paranagama, P., Amarasinghe, M., Senanayake, K., Dahanayake, K., Jayasumana, C. \& Fonseka, S. (2011) Chronic kidney Disease of unknown etiology (CKDu) and arsenic poisoning due to illegal pesticides. National science foundation.

Dharmawardana, M. W. C., Amarasiri, S. L., Dharmawardene, N. \& Panabokke, C. R. (2015). Chronic kidney disease of unknown aetiology and groundwater ionicity: study based on Sri Lanka. Environmental Geochemistry and Health, 37(2), pp.221. DOI:https://doi.org/10.1007/s10653-014-9641-4

Fernando, M. (2011) Fatal illness in north central province claims 20,000 in 20 years. Key to mystery killer disease found. Sunday Observer June 12.

Ferry, L. T., Akihiko, K. \& Mohammed, A. (2003). A conceptual Database Design for Hydrology using GIS. Proceeding of Asia pacific association of hydrology and water resources. Kyoto, Japan.

Gunatilake, S.K, Samaratunga S.S \& Rubasinghe R.Y. (2014) Chronic Kidney Disease (CKD) in Sri Lanka - current research evidence justification: A review. Sabaragamuwa University Journal, 13(2), pp.3158. ISSN 1391-3166; eISSN 2386-2041

DOI:http://dx.doi.org/10.4038/suslj.v13i2.7680

Illeperuma, O.A. (2000). Environmental pollution in Sri Lanka; A review. J. Natl. Sci. Found. Sri Lanka 28, pp.301-325.

Jayasekara, J. M., Dissanayake, D. M., Adhikari, S. B. \& Bandara, P. (2013). Geographical distribution of chronic kidney disease of unknown origin in North Central Region of Sri Lanka. The Ceylon Medical Journal, 58(November), pp. 610.

DOI:https://doi.org/10.4038/cmj.v58i1.5356

Jayasumana, M. A. C. S., Paranagama, P. A., Fonseka, M. A. \& Wijekoon, D. V. K. (2011) Presence of Arsenic in pesticides used in Sri Lanka. Proceedings of Water Professionals' Day Symposium, pp.18. URL:http://dl.nsf.ac.lk/handle/1/9552
Jayawardena, M. M. (2015). Development discourse of minor tank villages in Sri Lanka: a case study of three minor tank villages in Anuradhapura district, 4(12), pp.708 723. ISSN (Online): 2319-7064 DOI:http://dx.doi.org/10.21275/v4i12.nov151834

Katz, B.G., Berndt, M.P., Bullen, T.D. \& Hansard, P. (1999). Factors Controlling Elevated Lead Concentrations in Water Samples from Aquifer Systems in Florida, Water Resources Investigations Report 99-4020.

URL:https://fl.water.usgs.gov/PDF_files/ wri99_4020_katz.pdf

Keil, D.E., Berger-Ritchie, J. \& MacMillin, G.A. (2011). Testing for toxic elements: A focus on Arsenic, Cadmium, lead and Mercury, LABMEDICINE, 42(12), pp.735-742.

Kumari, M. K. N., Pathmarajah, S. \& Dayawansa, N. D. K. (2013). Characterization of agro-well water in Malwathuoya cascade in Anuradhapura district of Sri Lanka. Tropical agricultural research, 25(1), pp. 4655 .

DOI:http://doi.org/10.4038/tar.v25i1.8029

Kumari, M. K. N., Rathnayake, R., Kendaragama, K. M. A., Gunarathna, M. \& Nirmanee, K. G. S. (2016). Drinking water quality in chronic kidney disease of unknown aetiology (CKDu) prevalent and nonprevalent areas in Giradurukotte, Sri Lanka, 3(1), pp.36.

DOI:http://doi.org/10.13140/RG.2.1.3586.5686

Kumudumali M.M.L.U., Kumari M.K.N., Gunaratne M.H.J.P. \& Nimanee K.G.S. (2016). Surface Water quality in Ulagalla cascade- Anuradhapura district, pp. 18.

Mahatantila, K., Chandrajith, R., Jayasena, H. A. H. \& Ranawana, K. B. (2008). Spatial and temporal changes of hydro geochemistry in ancient tank cascade systems in Sri Lanka: Evidence for a constructed wetland. Water and Environment Journal, $22(1)$, pp.1724.

Mendis, S. (2011). Mission Report, Chronic Kidney disease of uncertain aetiology $(\mathrm{CKDu})$, Sri Lanka. World Health Organization, Geneva, Switzerland. $6-8^{\text {th }}$ June 2011.

URL:https://www.scribd.com/document/ 102940101/WHo-Full-Report

Misra, S. S. \& Saxena, P. (2012). Environmental contamination and its association with Chronic kidney disease of unknown aetiology in North Central region of Sri Lanka, pp.137.

Noble, A., Amerasinghe, P., Manthrithilake, H. \& Arasalingam, S. (2014). Review of literature on chronic kidney disease of unknown etiology ( $\mathrm{CKDu})$ in Sri Lanka: IWMI working paper 158. 
URL:http://www.iwmi.cgiar.org/Publications/ Working_Papers/working/wor158.pdf

Ratnayake, R., Gonawela, J. \& Wijekoon, D. (2012). Natural springs in the Anuradhapura district eng.pdf.

Sri Lanka Standards Organization (2012), Drinking water Standards- first Revision 614:2013.

Wanigasuriya, K. (2012). Aetiological factors of chronic kidney disease in the north central province of Sri Lanka: a review of evidence to-date. Journal of the College of Community Physicians of Sri Lanka, $17(1)$, pp. 2142 .

DOI:http://dx.doi.org/10.4038/jccpsl.v17i1.4931

Wasana, H.M.S., Aluthpatabendi, D. \& Bandara, J. (2012). Drinking water quality assessment towards "chronic kidney disease of unknown etiology $(\mathrm{CKDu})$ " in north central province (NCP) of Sri Lanka. International Symposium on Water Quality and Human Helath: Challenges Ahead, 2012.

URL:http://dl.nsf.ac.lk/bitstream/handle/1/9572/ 73.pdf? sequence $=1 \&$ isAllowed $=y$

Wasana, H. M. S., Aluthpatabendi, D., Kularatne, W. M. T. D., Wijekoon, P., Weerasooriya, R. \& Bandara, J. (2016) Drinking water quality and chronic kidney disease of unknown etiology (CKDu): Synergic effects of fluoride, cadmium and hardness of water. Environmental Geochemistry and Health, 38(1), pp.157168.

DOI:http://doi.org/10.1007/s10653-015-9699-7

Wimalawansa, S.J. (2014) Escalating chronic kidney diseases of multi-factorial origin in Sri Lanka: causes, solutions and recommendations. Environmental Health and Preventive Medicine (2014),19, pp.375-394.

DOI:http://doi.org/10.1007/s12199-014-0395-5

Wimalawansa, S. J. (2015). Agrochemicals and chronic kidney disease of multi-factorial origin (CKDmfo): An environmentally induced, occupational exposure disease. Int.J. Nephrol Kidney Failure, 1(3), pp.111. DOI:http://doi.org/10.1186/s40557-016-0119-y

World Health Organization (2011). Guidelines for Drinking-water quality, Fourth edition (http:// www.who.int) ISBN 9789241548151.

World Health Organization (2012). Investigation and Evaluation of Chronic Kidney Disease of Uncertain Aetiology in Sri Lanka Final report. Ministry of Health $(\mathrm{MoH})$ in Collaboration with World Health Organization. 